\title{
Synergistic effects of insulin-like growth factor I and gonadotrophins on relaxin and progesterone secretion by ageing corpora lutea of pigs*
}

\author{
C. J. Huang*, Y. Li, M. H. Stromer and L. L. Anderson $\dagger$ \\ Department of Animal Science, lowa State University, Ames, IA 50011, USA
}

\begin{abstract}
Summary. Insulin-like growth factor I (IGF-I) is involved in paracrine/autocrine regulation of gonadal steroidogenesis and peptide hormone biosynthesis. This study was designed to determine whether IGF-I alone, or an interaction of IGF-I, is involved in augmenting the actions of luteinizing hormone $(\mathrm{LH})$ and prolactin in controlling relaxin and progesterone secretion from ageing corpora lutea of hysterectomized gilts at days 110, 113 and 116 after oestrus. Luteal tissue slices were incubated for $8 \mathrm{~h}$ with IGF-I $\left(0,50,300 \mathrm{ng} \mathrm{ml}^{-1}\right)$, LH $\left(0,100,1000 \mathrm{ng} \mathrm{ml}^{-1}\right)$, and prolactin $(0,100$, $1000 \mathrm{ng} \mathrm{ml}^{-1}$ ) alone or in combination. Progesterone and relaxin concentrations were determined by radioimmunoassay of spent medium and of homogenates from luteal tissue slices before and after incubation. Porcine luteal tissue from day 110 had a net output of $25 \mathrm{ng}$ progesterone and $26 \mathrm{ng}$ relaxin in the control and of $65 \mathrm{ng}$ progesterone and $2125 \mathrm{ng}$ relaxin in the combined IGF-I, LH and prolactin treatment $\mathrm{mg}^{-1}$ of luteal tissue, respectively. IGF-I, LH and prolactin alone or in combination significantly increased $(P<0.01)$ progesterone production by luteal tissue from day 110 , but they were partially effective at day 113 and ineffective at day 116. By contrast, the same hormone treatments increased relaxin production by luteal tissue from days 110 and 113. Even at day 116, prolactin alone or with LH or IGF-I continued to stimulate relaxin production. In conclusion, IGF-I augments the ability of prolactin and LH to increase relaxin production by ageing corpora lutea; however, a decrease in progesterone secretion and an increase in relaxin secretion at day 113 indicate that different mechanisms control progesterone and relaxin secretion in pigs.
\end{abstract}

Keywords: IGF-I; gonadotrophins; relaxin; progesterone; ageing luteal cells; pig

\section{Introduction}

Relaxin and progesterone are produced by corpora lutea of pigs during pregnancy and after hysterectomy (Belt et al., 1970, 1971; Anderson et al., 1973, 1983). The corpora lutea from oestrous cycles of about 21 days secrete progesterone and small amounts of relaxin (Masuda et al., 1967; Anderson et al., 1973; Sherwood \& Rutherford, 1981). During a normal pregnancy of 114 days, circulating progesterone concentrations peak by day 8 and remain high until they decrease just before parturition. Relaxin accumulates in luteal tissue and increases gradually during pregnancy, and it is released into the blood in peak quantities just before parturition (Belt et al., 1971; Sherwood et al., 1981; Felder et al., 1986; Li et al., 1989). After hysterectomy of unmated gilts, the corpora lutea are maintained beyond the duration of the normal pregnancy; these ageing corpora lutea continue to secrete relaxin and progesterone. The profiles of decreased progesterone secretion

\footnotetext{
*Present address: John D. and Catherine T. MacArthur Foundation Fellow, Ethel Percey Andrus Gerontology Center, University of Southern California, Los Angeles, CA 90089-0191, USA.

†Reprint requests.
} 
and simultaneous increase in relaxin secretion from these ageing corpora lutea at day 113 were similar to those on the same day just preceding normal parturition (Felder et al., 1986; Li et al., 1989; Adair et al., 1989). Thus, hysterectomized pigs serve as an appropriate model to investigate the lifespan and hormonal secretion of corpora lutea of pigs. Relaxin and progesterone secretion from ageing corpora lutea of hysterectomized gilts are increased by prolactin and luteinizing hormone (LH) in vitro (Huang et al., 1991) and in vivo (Felder et al., 1988; Li et al., 1989). However, whether the increased relaxin secretion is caused by relaxin release from a preformed hormone pool or requires biosynthesis of the hormone is unknown. Furthermore, the interaction of prolactin with LH may play a role in steroidogenesis because physiological concentrations of LH increase the number of prolactin receptors (Chen et al., 1981), and prolactin can increase the number of LH receptors (Richards, 1978). Insulin-like growth factor I (IGF-I) is involved in gonadal steroidogenesis and peptide biosynthesis in an autocrine or paracrine manner (Adashi et al., 1985a; Kasson \& Hsueh, 1987; Caubo et al., 1989).

This study was designed to determine the roles of IGF-I, LH and prolactin alone and in combination on the regulation of relaxin and progesterone secretion from ageing corpora lutea of hysterectomized gilts during a period equivalent to late pregnancy and normal parturition in this species.

\section{Materials and Methods}

\section{Chemicals}

The following reagents were obtained from Sigma Chemical Co., St Louis, MO: Dulbecco's Modified Eagle's Medium (DMEM); bovine transferrin; low-density lipoprotein (LDL, from human plasma) and porcine insulin. Insulin-like growth factor I (IGF-I) was obtained from IMCERA Bioproducts Inc. (Terre Haute, IN). Porcine prolactin (USDA-pPRL-B-1) and porcine luteinizing hormone (USDA-pLH-B-1) were provided by D. J. Bolt, Reproduction Laboratory, USDA, Beltsville, MD, and S. Raiti, National Hormone and Pituitary Program, NIH, Baltimore, MD.

\section{Animals}

All ovaries were obtained by ovariectomy of purebred Yorkshire gilts previously hysterectomized at day 8 (oestrus = day 0), at days $110(n=5), 113(n=5)$ and $116(n=5)$ after oestrus. Anaesthesia was induced by i.v. injection of thiamylal sodium $(0.8-1.0 \mathrm{~g}$; Surital, Parke-Davis, Morris Plains, NJ) and maintained by a closed circuit system of halothane (4-9\%; Ayerst Laboratories, Rouses Point, NY) and $\mathrm{O}_{2}\left(500-1000 \mathrm{ml} \mathrm{min}^{-1}\right.$ ). Each corpus luteum was marked with a loop of black silk suture at hysterectomy for later identification. Corpora lutea from both ovaries of each of the 15 pigs were used for one incubation and for electron microscopy.

\section{Tissue incubation}

The corpora lutea were dissected from the ovarian stroma and trimmed immediately. Luteal slices averaging $0.4 \mathrm{~mm}$ thickness (each weighing about $50-60 \mathrm{mg}$ ) were cut with a microtome. Three luteal slices from each pig were saved to determine hormone storage at time zero. One tissue slice per well in a 24 -well, flat-bottom culture plate with cover lid (Falcon 3847, Becton Dickinson Labware, Lincoln Park, NJ) was incubated for $8 \mathrm{~h}$ in a Dubnoff Metabolic Shaking Incubator at $37^{\circ} \mathrm{C}, 5 \% \mathrm{CO}_{2}, 95 \% \mathrm{O}_{2}$ with an oscillating speed of 60 cycles min ${ }^{-1}$. Hormone treatments (each in triplicate) added to the incubation media were 0,50 , and $300 \mathrm{ng} \mathrm{ml}^{-1}$ IGF-I; 0,100 , and $1000 \mathrm{ng} \mathrm{ml}^{-1}$ $\mathrm{LH}$; and 0,100 , and $1000 \mathrm{ng} \mathrm{ml}^{-1}$ prolactin. The greatest concentration of each hormone was used in two- and three-factorial combinations to test hormonal interactions. The incubation medium $\left(\mathrm{l} \mathrm{ml} \mathrm{well}{ }^{-1}\right)$ was DMEM supplemented with LDL $\left(10 \mu \mathrm{g} \mathrm{ml}^{-1}\right)$, insulin $\left(5 \mu \mathrm{g} \mathrm{ml}^{-1}\right)$ and transferrin $\left(5 \mu \mathrm{g} \mathrm{ml}^{-1}\right)$. Appropriate controls were included in luteal tissue incubations for each series of hormone treatments. Relaxin and progesterone concentrations were determined by radioimmunoassay of spent medium from each incubation well. Each luteal tissue slice was blotted, weighed and homogenized for the hormone assays. The incubation procedure for the hormone treatments described here was carried out independently for each of the 15 animals in the study.

\section{Electron microscopy}

Fixation and dehydration of the luteal tissue were performed at $2^{\circ} \mathrm{C}$. Surgical specimens were immediately immersed in fixative on dental wax. The fixative contained two aldehyde forms. Paraformaldehyde $(4 \%)$ was included 
because it is a smaller molecule that penetrates more rapidly. Because the methylene bridges formed when formaldehyde reacts with proteins require two successive reactions (addition and condensation) and because the small size of the formaldehyde molecule cannot form bridges between some of the reactive groups on proteins, we also included glutaraldehyde, a dialdehyde that is a potent protein cross-linker. The tissue was cut into cubes $<1 \mathrm{~mm}$ on a side and fixed for $3 \mathrm{~h}$ in $2.5 \%$ glutaraldehyde in Millonig's phosphate buffer, $\mathrm{pH} 7 \cdot 25$. Silver sections $(70-80 \mathrm{~nm})$ were cut on a glass knife with an LKB Ultrotome III microtome (LKB Instruments, Rockville, MD). The thin sections were doublestained, first with $2 \%$ uranyl acetate in methanol and then with lead citrate, and examined in a JEOL-100CXII electron microscope (Adair et al., 1989). From each of the 15 gilts in this study, 21 blocks of luteal tissue were fixed of which two blocks were randomly selected for electron microscopy. If the fine structure of those two samples differed, another two blocks were randomly selected for electron microscopy to ensure that samples were representative of the luteal tissue. Six micrographs were prepared from each block for selection of photomicrographs representative of luteal cells from days 110,113 and 116.

\section{Radioimmunoassay of progesterone}

The procedures for radioimmunoassay of progesterone in the incubation medium and luteal tissue homogenates were similar to those described by Felder et al. (1986). Progesterone antibody (GDN 337) was generously supplied by G. D. Niswender (Department of Physiology and Biophysics, Colorado State University, Fort Collins). Briefly, progesterone concentrations in the incubation medium were assayed in duplicate $50 \mu \mathrm{l}$ aliquots of a 1:50 dilution. Assay sensitivity for the incubation medium was $50 \mathrm{pg}$ per tube (range $50-10000 \mathrm{pg}$ ). To determine the precision and accuracy of this assay, we added $0,50,100,250,500,1000,2500,5000$ and 10000 pg progesterone in quadruplicate aliquots of $50 \mu \mathrm{l}$ incubation medium. These standard samples were assayed; blank values were subtracted; and the concentrations of progesterone averaged ( \pm SEM) $0,46 \pm 5,100 \pm 8,226 \pm 15,547 \pm 15,1027 \pm 44,2835 \pm 96$, $5027 \pm 111$ and $9179 \pm 118 \mathrm{pg}(50 \mu \mathrm{l})^{-1}$, respectively. Replicate samples were included in each assay for determination of intra- and interassay variances which were $7.5 \%(n=9)$ and $9.6 \%(n=9)$, respectively. Nonspecific binding was $3.7 \%$ and the maximal antibody binding was $34.3 \%$. Progesterone contents in luteal tissue slices (i.e. $50-60 \mathrm{mg}$ ) were quantified in duplicate $50 \mu \mathrm{l}$ samples of a 1:100 dilution of the homogenate of fresh tissue (i.e. equivalent to $0.5 \mathrm{mg} \mathrm{m}^{-1} 0.01 \mathrm{~mol} \mathrm{PBS}^{-1}$ ). The assay sensitivity was $50 \mathrm{pg}$ per tube (range $50-10000 \mathrm{pg}$ ). The intra- and interassay variances were $7.8 \%$ and $11.5 \%$, respectively. Nonspecific binding was $2.8 \%$ and the maximal antibody binding was $34 \cdot 8 \%$.

\section{Radioimmunoassay of relaxin}

The procedures for radioimmunoassay of relaxin in the incubation medium and luteal tissue homogenates were similar to those described by Felder et al. (1986). Monotyrosyl relaxin for radiolabelling with ${ }^{125}$ I was generously provided by C. Schwabe (Department of Biochemistry, Medical University of South Carolina, Charleston). Briefly, relaxin concentrations in the incubation medium were assayed in duplicate $50 \mu 1$ aliquots of a 1:2000 dilution. Assay sensitivity for the incubation medium was $50 \mathrm{pg}$ per tube (range $50-5000 \mathrm{pg}$ ). To determine the precision and accuracy of this assay, we added $0,50,100,1000,2000,4000$, and $5000 \mathrm{pg}$ purified porcine relaxin to quadruplicate aliquots of $50 \mu$ incubation medium. The standard used for the relaxin radioimmunoassay was porcine relaxin (CM-B, 3000 units $\mathrm{mg}^{-1}$ ) and antibody was R6 antibody against porcine relaxin from B. G. Steinetz (New York University Medical Center, Tuxedo) and was previously described (O'Byrne \& Steinetz, 1976). These standard samples were assayed, blank values were subtracted and the concentrations of relaxin averaged ( \pm SEM) $0,54 \pm 13,95 \pm 13$, $1228 \pm 44,2261 \pm 85,3499 \pm 74$, and $5003 \pm 70 \mathrm{pg}$ in $50 \mu \mathrm{l}$, respectively. Replicate samples were included in each assay for determination of intra- and interassay variances which were $6.7 \%(n=9)$ and $9 \cdot 0 \%(n=9)$, respectively. Nonspecific binding was $3 \cdot 4 \%$ and maximal antibody binding was $34 \cdot 2 \%$. Relaxin contents in luteal tissue slices (i.e. $50-60 \mathrm{mg}$ ) were quantified in duplicate $50 \mu \mathrm{l}$ samples of a 1:4000 dilution of the homogenate of fresh tissue (i.e. equivalent to $12.5 \mu \mathrm{g} \mathrm{ml}^{-1}$ of $0.01 \mathrm{~mol} \mathrm{PBS} 1^{-1}$ ). The assay sensitivity was $50 \mathrm{pg}$ (range $50-5000 \mathrm{pg}$ ). The intra- and interassay variances were $6.3 \%(n=9)$ and $12.8 \%(n=9)$, respectively. Nonspecific binding was $2.8 \%$ and the maximal antibody binding was $34 \cdot 3 \%$.

\section{Protein determination}

The protein content in the extract of each luteal slice was determined spectrophotometrically using an acidic solution of Coomassie Brilliant Blue G-250 (500-600, Bio-Rad Protein Assay, Bio-Rad Chemical Division, Richmond, CA) and measuring the absorbance at $595 \mathrm{~nm}$ (Bradford, 1976). The assay standard was crystalline BSA (Intergen Co., Purchase, NY).

\section{Statistical analysis}

Data were analysed by least square analysis of variance using the General Linear Models procedure of the Statistical Analysis System (SAS, 1985). The experimental units are luteal tissue slices in the culture wells. The effects 
of treatments were tested by pooling the data within a day and the least significant difference was applied using day $\times$ treatment as error term to compare treatment means with the control value within that day (Snedecor \& Cochran, 1989).

\section{Results}

Without incubation, progesterone and relaxin contents were greater $(P<0.01, P<0.05)$ at day 110 than those at days 113 and 116 (Table 1). After $8 \mathrm{~h}$ incubation, the output of progesterone in the medium and in the luteal tissue was greater than that in tissue without incubation (within a day). However, incubation for $8 \mathrm{~h}$ did not increase the output of relaxin secretion on days 110,113 and 116 (Table 1).

Table 1. Mean progesterone and relaxin contents in incubation medium and in luteal tissues from hysterectomized pigs before and after $8 \mathrm{~h}$ incubation at days 110,113 and 116 (hysterectomy performed at day 8 , oestrus $=$ day 0 )

\begin{tabular}{lccccccc}
\hline $\begin{array}{l}\text { Hormones } \\
\text { in tissue } \\
+ \text { medium }\end{array}$ & \multicolumn{3}{c}{ Progesterone $\left(\mathrm{ng} \mathrm{mg}^{-1}\right.$ tissue) } & & \multicolumn{3}{c}{ Relaxin (ng mg ${ }^{-1}$ tissue) } \\
\cline { 2 - 3 } \cline { 7 - 8 } & day 110 & day 113 & day 116 & & day 110 & day 113 & day 116 \\
\hline $\begin{array}{l}\text { Before incubation } \\
\text { After incubation }\end{array}$ & $153 \pm 14^{\mathrm{a}}$ & $129 \pm 14^{\mathrm{b}}$ & $134 \pm 7^{\mathrm{b}}$ & & $3475 \pm 74^{\mathrm{c}}$ & $3140 \pm 118^{\mathrm{b}}$ & $3176 \pm 75^{\mathrm{b}}$ \\
\hline
\end{tabular}

Values are means and SEM, each from 15 samples of 5 pigs (only data from control incubations were included).

Means within columns and rows with different superscript letters are significantly different from each other: $a: b$ at $P<0.01 ;$ b:c at $P<0.05$.

At day 110 , IGF-I at a concentration of 50 or $300 \mathrm{ng} \mathrm{ml}^{-1}$ alone did not increase progesterone secretion (Fig. 1). Luteinizing hormone at 100 or $1000 \mathrm{ng} \mathrm{ml}^{-1}$, and prolactin at $100 \mathrm{ng} \mathrm{ml}^{-1}$ alone stimulated a significant $(P<0.05)$ progesterone release into the medium compared with that in the control. Luteinizing hormone and prolactin in combination induced a greater $(P<0.05)$ release of progesterone than $\mathrm{LH}$ alone. At day 113 , only $\mathrm{LH}$ at a concentration of $100 \mathrm{ng} \mathrm{ml}^{-1}$, LH plus prolactin, or LH plus prolactin and IGF-I stimulated $(P<0.05)$ progesterone secretion. At day 116, the capacity of these ageing luteal tissues to respond to trophic stimulation was lost (Fig. 1). Relaxin secretion followed a somewhat different pattern. At day 110, IGF-I at a concentration of $50 \mathrm{ng} \mathrm{ml}^{-1}$ alone or in the presence of LH or prolactin induced a significant release of relaxin compared with that in the control (Fig. 2). At day 113, IGF-I at $300 \mathrm{ng} \mathrm{ml}^{-1}$ alone or in the presence of LH with or without prolactin, $\mathrm{LH}$ at $100 \mathrm{ng} \mathrm{m}^{-1}$, and prolactin at $1000 \mathrm{ng} \mathrm{m}^{-1}$ stimulated $(P<0.05)$ relaxin secretion. At day 116 , only IGF-I at a concentration of 50 or $300 \mathrm{ng} \mathrm{ml}^{-1}$ induced a greater release of relaxin than in the controls.

Net progesterone and relaxin production was defined as the difference in hormone concentration in luteal tissue and medium after $8 \mathrm{~h}$ compared with $0 \mathrm{~h}$ incubation (Figs 3 and 4). This net hormone production resulted from the biosynthesis of progesterone and relaxin by luteal tissue in response to different hormone challenges during the $8 \mathrm{~h}$ incubation. All hormone treatments at day 110 increased net progesterone biosynthesis (Fig. 3). At day 113, only LH alone or combined with prolactin significantly stimulated progesterone biosynthesis. By day 116 , all hormone treatments were ineffective, but net progesterone production remained unchanged from that of the controls at days 110 and 113 (Fig. 3). Over all treatments, net progesterone concentration at day 110 averaged $48 \pm 4 \mathrm{ng} \mathrm{mg}^{-1}$ luteal tissue, which was significantly greater $(P<0.05)$ than $36 \pm 3 \mathrm{ng} \mathrm{mg}^{-1}$ at day 113 , and $34 \pm 1 \mathrm{ng} \mathrm{mg}^{-1}$ at day 116 . 


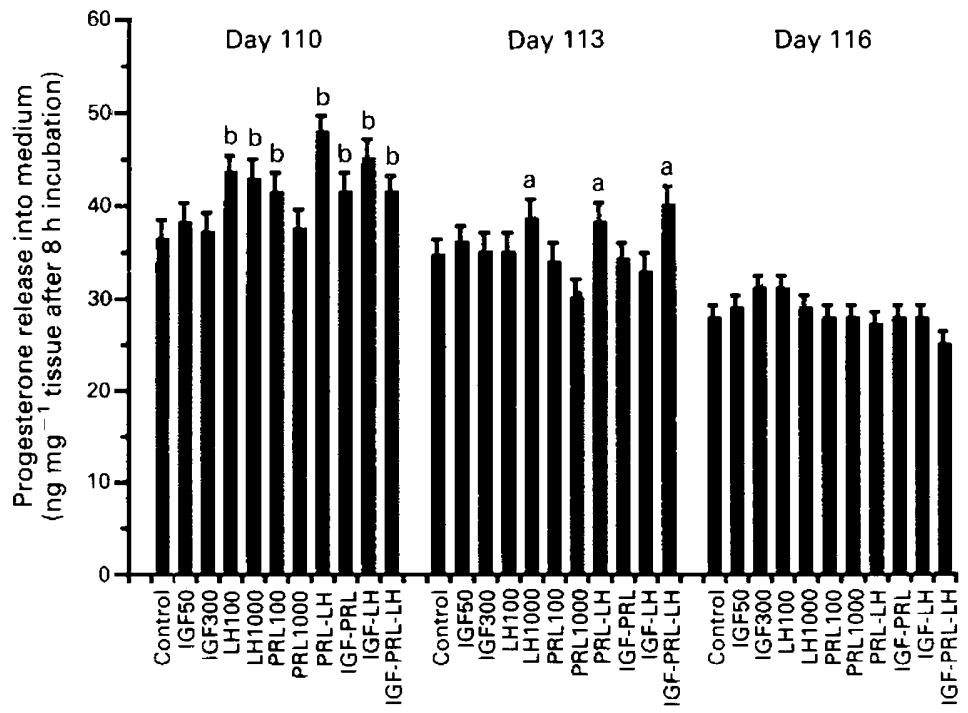

Fig. 1. Progesterone release into the medium after $8 \mathrm{~h}$ incubation by ageing luteal tissue from hysterectomized pigs at days 110,113 and 116 (hysterectomy performed at day 8 , oestrus $=$ day $0)$. Treatments are insulin-like growth factor-I (IGF, 0, 50, 300 $\mathrm{ng} \mathrm{m}^{-1}$ ), luteinizing hormone ( $\mathrm{LH}, 0,100,1000 \mathrm{ng} \mathrm{ml}^{-1}$ ) and prolactin (PRL, 0, 100, 1000 $\mathrm{ng} \mathrm{ml}^{-1}$ ); the greatest dose of each tested hormone was used in two- or three-factor combination. Values are means \pm SEM. Comparison with control $\left({ }^{\mathrm{a}} P<0.05 ;^{\mathrm{b}} P<0.01\right)$ was made within a day $(n=5$ animals; treatment replication $=3$ within animal and day).

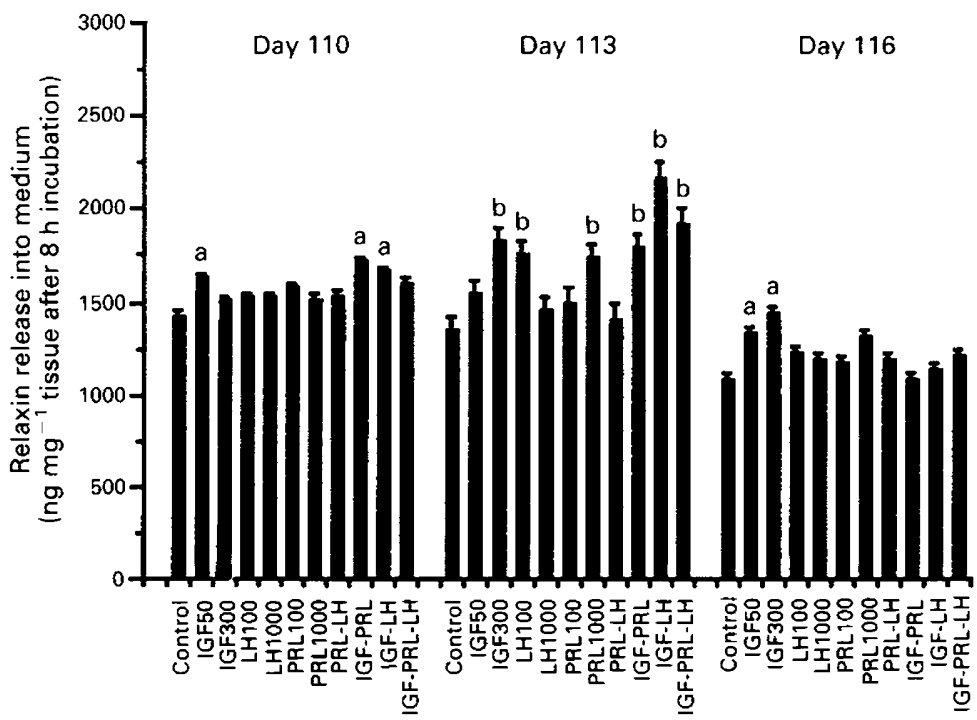

Fig. 2. Relaxin release into the medium after $8 \mathrm{~h}$ incubation of ageing luteal tissue from hysterectomized pigs at days 110,113 and 116 (hysterectomy performed at day 8 , oestrus $=$ day 0 ). Treatments are insulin-like growth factor I (IGF, $0,50,300 \mathrm{ng} \mathrm{ml}^{-1}$ ), luteinizing hormone ( $\mathrm{LH}, 0,100,1000 \mathrm{ng} \mathrm{ml}^{-1}$ ) and prolactin (PRL, 0, 100,1000 $\mathrm{ng} \mathrm{m}^{-1}$ ); the greatest dose of each tested hormone was used in two- or three-factor combinations. Values are means \pm SEM. Comparison with control $\left({ }^{\mathrm{a}} P<0.05 ;{ }^{\mathrm{b}} P<0.01\right)$ was made within a day $(n=5$ animals; treatment replication $=3$ within animal and day). 


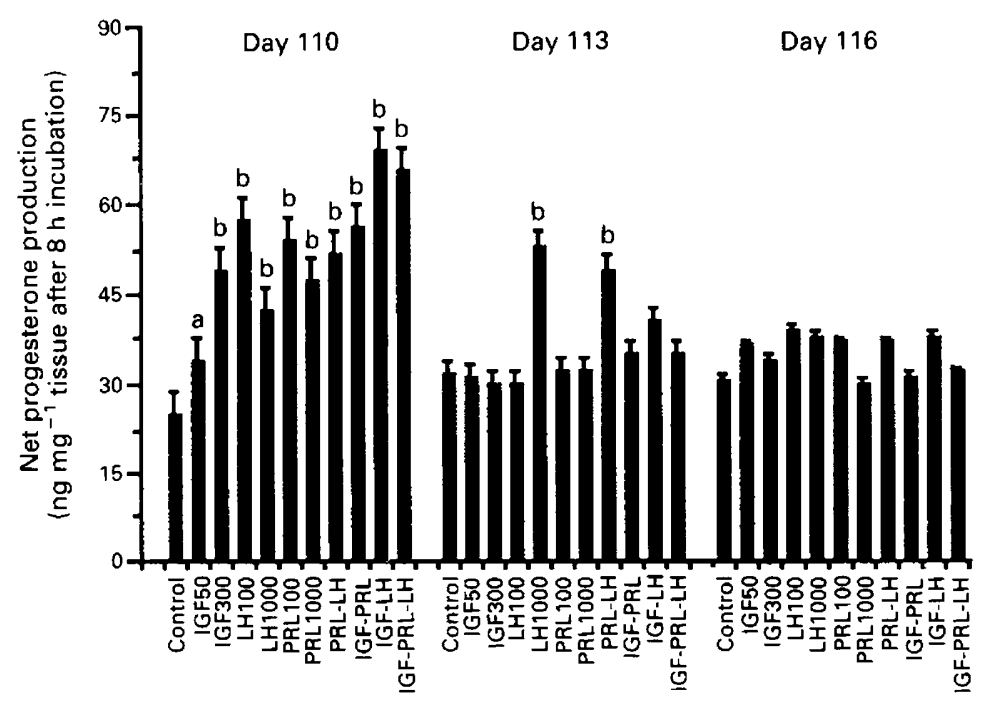

Fig. 3. Net progesterone release during $8 \mathrm{~h}$ incubation by ageing luteal tissue from hysterectomized pigs at days 110,113 and 116 (hysterectomy performed at day 8 , oestrus $=$ day 0 ). Treatments are insulin-like growth factor I (IGF, 0, 50, 300 $\mathrm{ng} \mathrm{ml}^{-1}$ ), luteinizing hormone (LH, 0, 100, $1000 \mathrm{ng} \mathrm{ml}^{-1}$ ) and prolactin (PRL, 0, 100, $1000 \mathrm{ng} \mathrm{ml}^{-1}$ ); the greatest dose of each tested hormone was used in two- or three-factor combinations. Values are means \pm SEM. Comparison with control $\left({ }^{\mathrm{a}} P<0.05 ;{ }^{\mathrm{b}} P<0.01\right)$ was made within a day $(n=5$ animals; treatment replication $=3$ within animal and day).

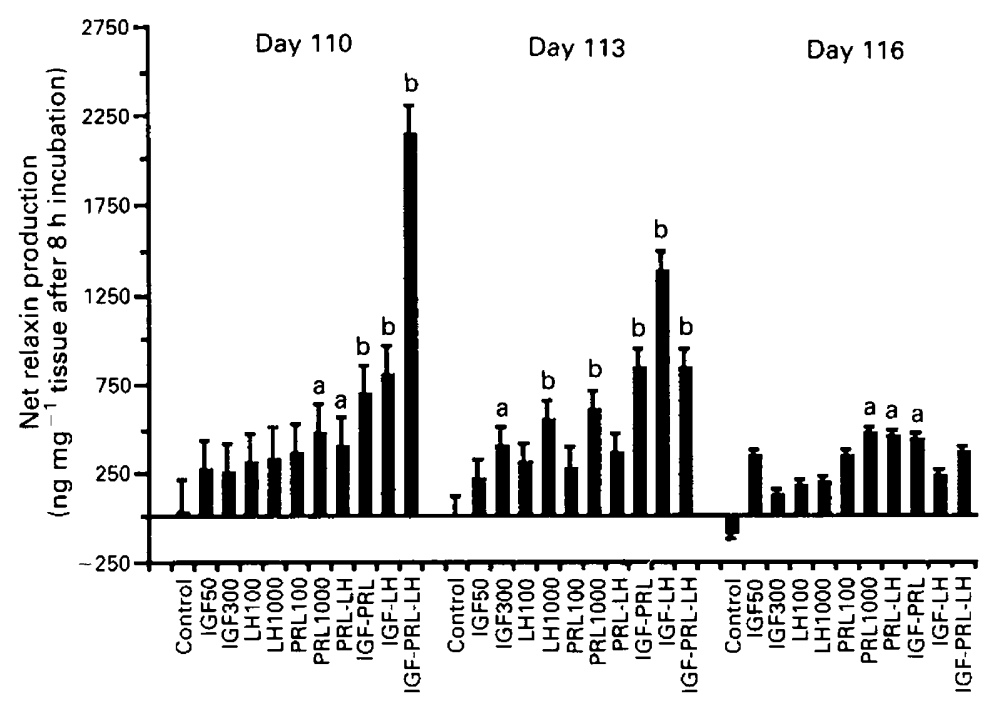

Fig. 4. Net relaxin release during $8 \mathrm{~h}$ incubation by ageing luteal tissue from hysterectomized pigs at days 110,113 and 116 (hysterectomy performed at day 8 , oestrus $=$ day 0 ). Treatments are insulin-like growth factor I (IGF, $0,50,300 \mathrm{ng} \mathrm{ml}^{-1}$ ), luteinizing hormone ( $\mathrm{LH}, 0,100$, $1000 \mathrm{ng} \mathrm{ml}^{-1}$ ) and prolactin (PRL, 0, 100,1000 $\mathrm{ng} \mathrm{ml}^{-1}$ ); the greatest dose of each tested hormone was used in two- or three-factor combinations. Values are means \pm SEM. Comparison with control ( ${ }^{\mathrm{a}} P<0.05$; $\left.{ }^{\mathrm{b}} P<0.01\right)$ was made within a day $(n=5$ animals; treatment replication $=3$ within animal and day). 
At day 110 , prolactin alone and combined with LH or IGF-I stimulated relaxin biosynthesis (Fig. 4). The greatest increase $(P<0.001$ compared with control; $P<0.01$ compared with other treatments at day 110) in relaxin biosynthesis resulted when IGF-I was combined with prolactin and $\mathrm{LH}$ at this time. A similar response to gonadotrophin treatments was seen at day 113 , but the greatest net production of relaxin occurred when IGF-I was combined with LH or prolactin. Only prolactin alone or combined with LH or IGF-I increased $(P<0.05)$ relaxin biosynthesis at day 116. The negative value for the controls at day 116 may reflect relaxin degradation with little or no hormone biosynthesis during the $8 \mathrm{~h}$ incubation. Over all treatments, relaxin concentration at day 110 was $547 \pm 165 \mathrm{ng} \mathrm{mg}^{-1}$ luteal tissue, which was similar to $496 \pm 110 \mathrm{ng} \mathrm{mg}^{-1}$ at day 113 and
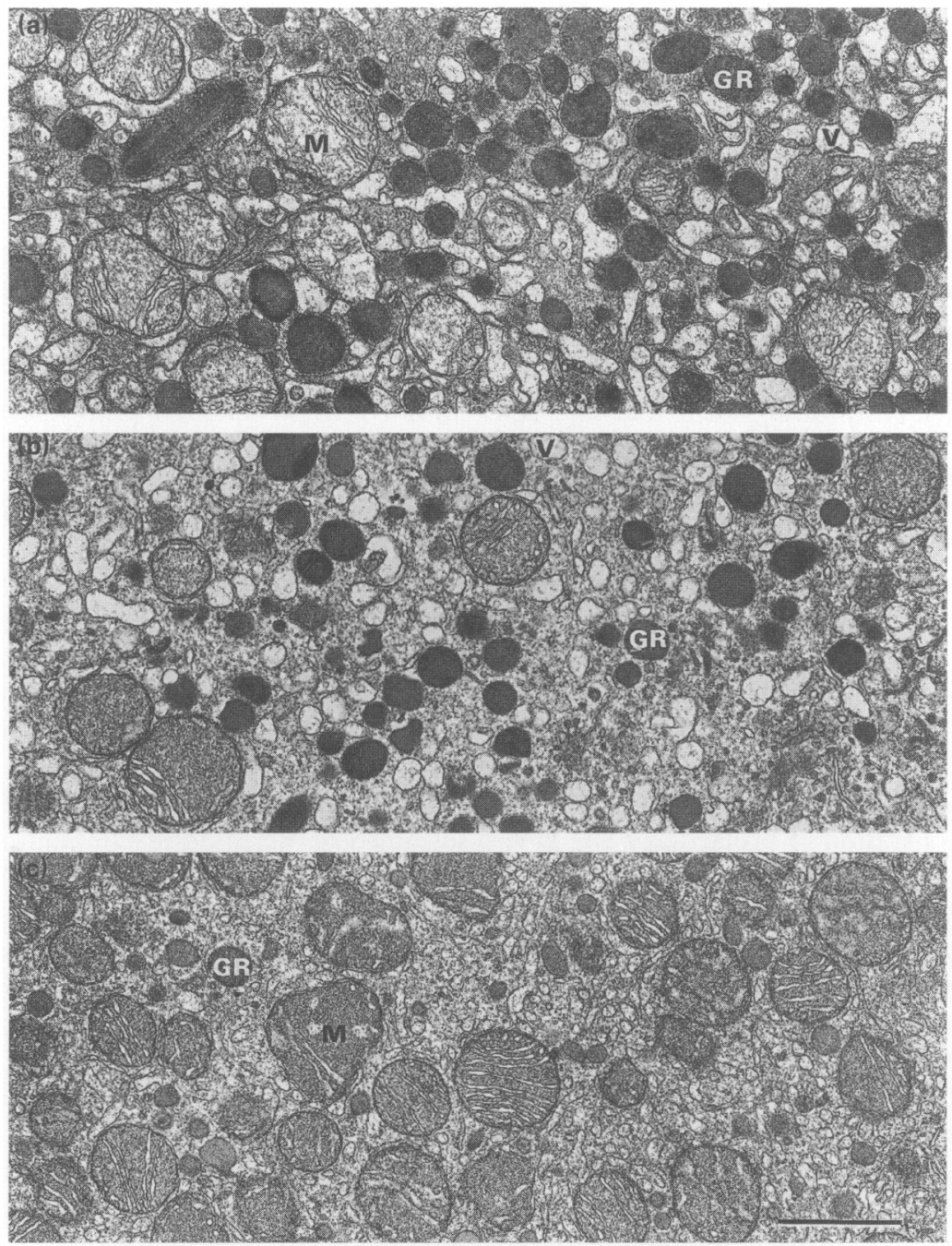

Fig. 5. (a) Luteal tissues removed at day 110 after hysterectomy contain abundant electrondense cytoplasmic granules (GR). Vesicles (V) and mitochondria (M) of various sizes are prominent. (b) Luteal tissues removed at day 113 after hysterectomy also contain a considerable number of cytoplasmic granules (GR); more vesicles (V) were seen. (c) Luteal tissues removed at day 116 of hysterectomy contain fewer cytoplasmic granules (GR). An invasion of collagen between the luteal cells was seen, and there are enlarged mitochondria (M) that had fewer fenestrated lamelliform cristae. Bar $=1 \mu \mathrm{m}$. 
greater $(P<0.05)$ than $200 \pm 48 \mathrm{ng} \mathrm{mg}^{-1}$ seen at day 116 . There was a high correlation $(r=0.93$ for progesterone, 0.95 for relaxin, $P<0.01$ ) between hormone concentration expressed as $\mathrm{ng} \mathrm{mg}^{-1}$ luteal tissue and $\mathrm{ng} \mathrm{mg}^{-1}$ protein; thus, the results were expressed as $\mathrm{ng} \mathrm{mg}^{-1}$ luteal tissue.

Luteal tissue from these hysterectomized gilts at day 110 contained maximum numbers of electron-dense granules in the cytoplasm, which were distributed in clusters among abundant large mitochondria (Fig. 5a). Vesicles were interspersed among the Golgi complexes. A granular or smooth endoplasmic reticulum (SER) and granular or rough endoplasmic reticulum were present at day 110 as well as at days 113 and 116, but SER was far more abundant. By day 113, there were slightly fewer cytoplasmic granules than at day 110 , and more vesicles appeared (Fig. 5b). Fewer cytoplasmic granules and more small vesicles were seen by day 116 (Fig. 5c). An invasion of collagen between the luteal cells was evident at this time. Mitochondria were enlarged and had fewer fenestrated lamelliform cristae. Large lipid bodies and multilamellar bodies were also frequently seen in day 116 samples (data not shown).

\section{Discussion}

The results from this study show that IGF-I augments relaxin production and release by ageing luteal tissue removed from hysterectomized gilts at days 110 and 113 after oestrus when co-incubated for $8 \mathrm{~h}$ with $\mathrm{LH}$ and prolactin. By day 116, however, relaxin production in response to these hormones was marginal. Progesterone production and release was increased by IGF-I alone and further increased when prolactin with or without LH were added to the incubation at day 110 , but not at days 113 and 116. Thus these trophic hormone responses of ageing luteal tissues to IGF-I and gonadotrophins depend on day of treatment and there is a distinct difference between relaxin and progesterone secretion. Although these results from luteal slice incubations were similar to those from dispersed monolayer culture of porcine luteal cells at the same stages (Huang et al., 1991), IGF-I distinctly increased relaxin production at days 110 and 113 when added to the incubation with gonadotrophins. These patterns of relaxin and progesterone secretion by incubated luteal slices parallel the relaxin surge release that is coincident with decreased progesterone concentrations in the peripheral blood at the same stages of pregnant and hysterectomized gilts (Felder et al., 1986, 1988; Li et al., 1989). These results suggest that ageing corpora lutea may be programmed to have an inherent lifespan of approximately 113 days.

Prolactin is luteotrophic for ageing corpora lutea in this species (Felder et al., 1988; Li et al., 1989). Administration of prolactin or LH in vivo sustained or increased relaxin and progesterone concentrations in the peripheral blood, which maintained or increased luteal weight. Whether the high hormone concentrations result from an increased rate of secretion in vivo is unresolved. Results from dispersed monolayers of luteal cells in culture indicate that prolactin and $\mathrm{LH}$ increase the rates of relaxin and progesterone secretion (Grinwich et al., 1983; Huang et al., 1991). Porcine luteal cells have prolactin-specific binding receptors (Rolland et al., 1976; Bramley \& Menzies, 1987) and LH can stimulate progesterone secretion by these cells from the oestrous cycle and early pregnancy (Lemon \& Loir, 1977; Hunter, 1981; Kineman \& Rampacek, 1987), which is consistent with the present findings with ageing corpora lutea.

In the present study, IGF-I or LH alone did not increase relaxin production, whereas a synergistic effect occurred when IGF-I was combined with LH with and without prolactin. This synergistic action between IGF-I and gonadotrophin or the combination of the three hormones indicates similar mechanisms, or at least some overlap, in their pathways to cause progesterone and relaxin synthesis and release. It has been shown that porcine granulosa cells may be sites of IGF-I production (Mondschein \& Hammond, 1988), receptors (Baranao \& Hammond, 1984) and hormone action (Veldhuis et al., 1986, 1987). Circulating concentrations of IGF-I are unrelated to the stage of ovarian function during the oestrous cycle in heifers, but this has not been determined in pigs (J. D. Armstrong, personal communication). It has been reported that IGF-I alone 
stimulated or potentiated gonadotrophin-induced steroidogenesis in porcine thecal cells (Caubo $e t$ al., 1989), bovine luteal cells (McArdle \& Holtorf, 1989) and rat granulosa cells (Adashi et al., $1985 \mathrm{a}, \mathrm{b})$. IGF-I binds the membrane receptor that has tyrosine kinase activity. Its action may be partly mediated by cAMP because IGF-I can increase adenylyl cyclase activity and stimulate cAMP-induced testosterone and progesterone biosynthesis (Lin et al., 1987). Dibutryl cAMP has been demonstrated to be a potent stimulator of relaxin and progesterone secretion from dispersed ageing luteal cells in culture (Huang et al., 1991). Alternatively, IGF-I may increase the numbers of LH receptors and LDL receptors in gonadal tissue. This contention is consistent with the report that IGF-I synergized with FSH in the induction of progesterone synthesis by an increase in numbers of LH receptors (Adashi et al., 1985b) and of LDL receptors in porcine granulosa cells with no change in their affinity (Veldhuis et al., 1987).

With the use of a serum-free chemically defined medium, insulin and transferrin are frequently included as important supplements to enhance the responses of the cell to hormone secretion. During steroidogenesis, IGF-I or insulin is required for the maintenance of this specific function of adrenal cells (Penhoat et al., 1988). In this study, addition of insulin at $5 \mu \mathrm{g} \mathrm{ml}^{-1}$ to the medium may not produce significant effects to mask those of IGF-I because the affinity of insulin to IGF-I receptor is 700 times less than that of IGF-I to its own receptors (Nissley \& Rechler, 1984; Davoren et al., 1986) and insulin at $10 \mu \mathrm{g} \mathrm{ml}^{-1}$ plus IGF-I at $50 \mathrm{ng} \mathrm{ml}^{-1}$ produced the same effect as IGF-I at $50 \mathrm{ng} \mathrm{ml}^{-1}$ alone in corticosterone secretion by the isolated adrenal cells (Penhoat et al., 1988). Accordingly, the addition of $5 \mu \mathrm{g}$ insulin $\mathrm{ml}^{-1}$ to the incubation medium may produce a potency equivalent to IGF-I at a concentration of $7 \mathrm{ng} \mathrm{ml}^{-1}$, and thus the added insulin in the present study may partly mask the effect of IGF-I when added at a concentration of $50 \mathrm{ng} \mathrm{ml}^{-1}$ to the incubation medium.

We determined whether relaxin in the medium is released from previous storage (including release from cell death) or from de novo synthesis. The hormone content at the beginning of the incubation was measured and subtracted from the total hormone content (both in the medium and in the tissue) after $8 \mathrm{~h}$ incubation. The results clearly indicate that the capacity of ageing luteal tissue to synthesize hormones is greatly reduced or lost at day 116 for relaxin, and at days 113 and 116 for progesterone. The different regulatory mechanisms between relaxin and progesterone secretion revealed in the present study are consistent with distinct intracellular pathways for relaxin (stored in cytoplasmic granule before release) and progesterone production and release.

The results of the present study indicate that ageing luteal tissues from hysterectomized gilts increase relaxin and progesterone production in response to incubation with IGF-I, LH and prolactin depending on the day of treatment. By day 116 , an inability to increase progesterone and relaxin secretion signalled the occurrence of regression in luteal tissues, which was supported by morphological evidence in the fine structure of these cells at days 110,113 and 116. Taken together, the distinct shifts in steroid and peptide hormone secretion and production patterns in luteal tissues during this brief period indicate that luteal tissue from hysterectomized gilts can mimic the events that occur in pregnant gilts at corresponding stages. This implies that incubated luteal tissues express their own species-specific lifespan of approximately 113 days.

We thank P. G. Eness (Ambulatory Clinics, College of Veterinary Medicine) for monitoring the health status of experimental animals; D. K. Hotchkiss (Department of Statistics) for assistance with statistical analysis; and A. I. Musah, H. H. Juang, N. Samari-Kermani, K. H. Smith, M. E. Shell, C. R. Bohnker and M. S. Mayes for excellent technical assistance. This work was supported in part by US Department of Agriculture, ARS, CSRS, OGPS Competitive Grant 88-37242-3918 and Iowa Biotechnology Council Competitive Grant AGD-86-2. This is Journal Paper J-14332 of the Iowa Agriculture and Home Economics Experiment Station, Ames, IA (Projects 2443, 2444, 2638, 2853 and 2896). 


\section{References}

Adair, V., Stromer, M.H. \& Anderson, L.L. (1989) Progesterone secretion and mitochondrial size of aging porcine corpora lutea. Anatomical Record 223, 252-256.

Adashi, E.Y., Resnick, C.E., D'Ercole, A.J., Svoboda, M.E. \& Van Wyk, J.J. (1985a) Insulin-like growth factors as intraovarian regulators of granulosa cell growth and function. Endocrine Reviews 6, 400-418.

Adashi, E.Y., Resnick, C.E., Brodie, A.M.H., Sroboda, M.E. \& Van Wyk, J.J. (1985b) Somatomedin-Cmediated potentiation of follicle-stimulating hormoneinduced aromatase activity of cultured rat granulosa cells. Endocrinology 117, 2313-2320.

Anderson, L.L., Ford, J.J., Melampy, R.M. \& Cox, D.F. (1973) Relaxin in porcine corpora lutea during pregnancy and after hysterectomy. American Journal of Physiology 225, 1215-1219.

Anderson, L.L., Adair, V., Stromer, M.H. \& McDonald, W.G. (1983) Relaxin production and release after hysterectomy in the pig. Endocrinology 113, 677-686.

Baranao, J.L.S. \& Hammond, J.M. (1984) Comparative effects of insulin and insulin-like growth factors on DNA synthesis and differentiation of porcine granulosa cells. Biochemical and Biophysical Research Communications 124, 484-498.

Belt, W.D., Anderson, L.L., Cavazos, L.F. \& Melampy, R.M. (1971) Cytoplasmic granules and relaxin levels in porcine corpora lutea. Endocrinology 89, 1-10.

Belt, W.D., Cavazos, L.F., Anderson, L.L. \& Kraeling, R.R. (1970) Fine structure and progesterone levels in the corpus luteum of the pig during pregnancy and after hysterectomy. Biology of Reproduction 2,98-113.

Bradford, M.M. (1976) A rapid and sensitive method for the quantitation of microgram quantities of protein utilizing the principle of protein-dye binding. Analytical Biochemistry 72, 248-254.

Bramley, T.A. \& Menzies, G.S. (1987) Receptors for lactogenic hormones in the porcine corpus luteum: properties and luteal phase concentrations. Journal of Endocrinology 113, 355-364.

Caubo, B., Devinna, R.S. \& Tonetta, S.A. (1989) Regulation of steroidogenesis in cultured porcine theca cells by growth factors. Endocrinology 125, 321-326.

Chen, T.T., Harwood, J.P. \& Catt, K.J. (1981) Actions of hCG, GnRH, and $\mathrm{PGF}_{2} \alpha$ in the luteinized rat ovary. In Dynamics of Ovarian Function, pp. 167-173. Eds N. B. Schwartz \& M. Hunzicker-Dunn. Raven Press, New York.

Davoren, J.B., Kasson, B.G., Li, C.H. \& Hsueh, A.J.W. (1986) Specific insulin-like growth factor (IGF) Iand II-binding sites on rat granulosa cells: relation to IGF action. Endocrinology 119, 2155-2162.

Felder, K.J., Klindt, J., Bolt, D.J. \& Anderson, L.L. (1988) Relaxin and progesterone secretion as affected by luteinizing hormone and prolactin after hysterectomy in the pig. Endocrinology 122, 1751-1760.

Felder, K.J., Molina, J.R., Benoit, A.M. \& Anderson, L.L. (1986) Precise timing for peak relaxin and decreased progesterone secretion after hysterectomy in the pig. Endocrinology 119, 1502-1509.

Grinwich, D.L., McKibbin, P.E. \& Murphy, B.D. (1983) Stimulation of progesterone secretion in the pregnant pig corpus luteum. In Factors Regulating Ovarian Function, pp. 123-127. Eds G. Greenwald \& P. F. Terranova. Raven Press, New York.

Huang, C.J., Stromer, M.H. \& Anderson, L.L. (1991) Abrupt shifts in relaxin and progesterone secretion by aging luteal cells: luteotropic response in hysterectomized and pregnant pigs. Endocrinology 128, $165-173$.

Hunter, M.G. (1981) Responsiveness in vitro of porcine luteal tissue recovered at two stages of the luteal phase. Journal of Reproduction and Fertility 63, $471-476$.

Kasson, B.G. \& Hsueh, A.J.W. (1987) Insulin-like growth factor-I augments gonadotropin-stimulated androgen biosynthesis by cultured rat testicular cells. Molecular and Cellular Endocrinology 52, 27-34.

Kineman, R.R. \& Rampacek, G.B. (1987) Comparison of induced corpora lutea from prepubertal gilts and spontaneous corpora lutea from mature gilts: in vitro progesterone production. Journal of Animal Science 64, $526-532$.

Lemon, M. \& Loir, M. (1977) Steroid release in vitro by two luteal cell types in the corpus luteum of the pregnant sow. Journal of Endocrinology 72, 351-359.

Li, Y., Molina, J.R., Klindt, J., Bolt, D.J. \& Anderson, L.L. (1989) Prolactin maintains relaxin and progesterone secretion by aging corpora lutea after hypophysial stalk transection or hypophysectomy in the pig. Endocrinology 124, 1294-1304.

Lin, T., Vinson, N., Haskett, J. \& Murono, E.P. (1987) Inducton of 3- $\beta$-hydroxysteroid dehydrogenase activity by insulin-like growth factor-I in primary culture of purified Leydig cells. Advances in Experimental Medicine and Biology 219, 603-607.

McArdle, C.A. \& Holtorf, A.P. (1989) Oxytocin and progesterone release from bovine corpus luteal cells in culture: effects of insulin-like growth factor I, insulin, and prostaglandins. Endocrinology 124, $1278-1286$

Masuda, H., Anderson, L.L., Henricks, D.M. \& Melampy, R.M. (1967) Progesterone in ovarian venous plasma and corpora lutea of the pig. Endocrinology 80, 240-246.

Mondschein, J.S. \& Hammond, J.M. (1988) Growth factors regulate immunoreactive insulin-like growth factor-I production by cultured porcine granulosa cells. Endocrinology 123, 463-468.

Nissley, S.P. \& Rechler, M.M. (1984) Somatomedin/ insulin-like growth factor tissue receptors. Clinical Endocrinology and Metabolism 13, 43-48.

O'Byrne, E.M. \& Steinetz, B.G. (1976) Radioimmunoassay of relaxin in sera of various species using an antiserum to porcine relaxin. Proceedings of the Society for Experimental Biology and Medicine 152, $272-276$.

Penhoat, A., Chatelain, P.G., Jaillard, C. \& Saez, J.M. (1988) Characterization of insulin-like growth factor 1 and insulin receptors on cultured bovine adrenal fasciculata cells, role of these peptides on adrenal cell function. Endocrinology 122, 2518-2526.

Richards, J.S. (1978) Hormonal control of ovarian follicular development. Recent Progress in Hormone Research 35, 343-368.

Downloaded from Bioscientifica.com at 04/26/2023 01:27:30PM 
Rolland, R., Gunsalus, G.L. \& Hammond, J.M. (1976) Demonstration of specific binding of prolactin by porcine corpora lutea. Endocrinology 98, 1083-1091.

SAS Institute Inc. (1985) Users Guide: Statistics Version (5th Edn), pp. 443-506. SAS Institute Inc., Cary.

Sherwood, O.D., Nara, B.S., Welk, F.A., First, N.L. \& Rutherford, J.E. (1981) Relaxin levels in the maternal plasma of pigs before, during and after parturition and before, during and after suckling. Biology of Reproduction 25, 65-71.

Sherwood, O.D. \& Rutherford, J.E. (198I) Relaxin immunoactivity levels in ovarian extracts obtained from rats during various reproductive states and from adult cycling pigs. Endocrinology 108, 1171-1177.
Snedecor, G.W. \& Cochran, W.G. (1989) Statistical Methods (8th Edn), pp. 254-272. Iowa State University Press, Ames.

Veldhuis, J.D., Nestler, J.E. \& Strauss, J.F. (1987) The insulin-like growth factor, somatomedin-C, modulates low density lipoprotein metabolism by swine granulosa cells. Endocrinology 121, 340-346.

Veldhuis, J.D., Rodgers, R.J., Dee, A. \& Simpson, E.R. (1986) The insulin-like growth factor, somatomedin $\mathrm{C}$, induces the synthesis of cholesterol side-chain cleavage cytochrome $\mathrm{P}-450$ and adrenodoxin in ovarian cells. Journal of Biological Chemistry 261, 2499-2502.

Received 10 July 1991 